FZMw Jg. 10 (2007) S. 26-70

\title{
Interpreting Compositional Process in Wolfgang Rihm's Chiffre Cycle
}

\author{
by Richard McGregor
}

In Rihm's output the Chiffre Tatble 3works occupy a pivotal position. Despite some prefiguring in certain earlier works, such as the last movement of the fourth quartet, these are works which, as he has said, embody a conscious search for a musical language, a means of expression ('Die Stücke ... sind Versuche, eine Musiksprache zu finden'). ${ }^{1}$ The purpose of this article is to try to define key elements of the compositional process which Rihm developed through the Chiffre works.

\section{The Chiffre works: introduction}

The Chiffre cycle comprises seven works with that title written between 1983 and 1985, and an eighth added in 1988. Related to the cycle is Bild (1984), which Rihm describes as a 'self-standing composition in the orbit of the Chiffre cycle ${ }^{12}$ and it is included in the following discussion on account of its relationship to Chiffre VI in particular. Other compositions which may also be related to the cycle are Fusées (1984) and Gebild (1982-3) which includes, like Bild, a part for high trumpet. Gebild was extended in 1997 with a more substantive part for the trumpet. There was an abortive beginning to a work in this series given the title Tonspur, but only six bars were written and it is likely that this work became Bild: not Spur as might be expected. ${ }^{3}$

In order to give some sense of the compositional development taking place in this series of works, the following article is in two parts. The first part sets out an essential grammar for understanding Rihm's Chiffre works, while the second part uses this grammar to develop an analytical understanding of Chiffre $V I$ and to explore relationships with other works in the cycle. The first part deals primarily with the founding works, Chiffre and Chiffre II, because this is where Rihm's compositional processes for the cycle were established. Less attention is given to Chiffre III- $V$ since one of Rihm's guiding principles - that 'a sound transforms its predecessor ${ }^{4}$ - indicates that later works in the cycle can only be understood in

1 Rihm, Ausgesprochen, Vol. II, p. 343.

2 Rihm, Ausgesprochen, vol. II, p. 335. In 2004 Rihm made a rearrangement (Bearbeitung) of Chiffre [I] under the title Nach-Schrift (eine Chiffre). This is part of the process of revisiting works - effectively 'repainting them' - which has connections with his understanding of music as an art form related to the visual arts. However, further discussion of this idea lies outside the scope of the present article.

3 Spur ('track' or 'trace') is an orchestral piece, or rather, an orchestra-sketch, written in 1984-85 but apparently unrelated to the Chiffre cycle.

$4 \quad$ 'Ein Klang, der einem anderen Klang zeitlich folgt, formt seinen Vorgänger wirklich um' ('A sound, which temporally follows another sound, really transforms its predecessor') from 'Mutation (Exkurse)', in, Rihm, Ausgesprochen, Vol. I, p. 159. 
relation to what has gone before. The choice of Chiffre VI as the main focus for the second part of this article is not conditioned by its being summative in nature: that distinction belongs to Chiffre VII insofar as it is a relevant way of viewing the cycle as a whole. However the reasons for choosing Chiffre VI as a focus will become apparent in due course.

Rihm's first published use of the word chiffre was in a programme note for Sub-Kontur (1974-5) and, in the same year, in a programme note for the second symphony (1975). ${ }^{5}$ Originally an Arabic word signifying zero, the word exists with multiple meanings in French, Italian and English (in the form 'cipher') but in German usage it is borrowed from French and can mean a symbol, a box, a code, a sign, or a key. These multiple meanings of the word can be applied to the way the music should be heard, as will be discussed later. Rihm drew inspiration from Artaud in the creation of 'a new form of musical expression that would be immediate and direct; that would be understandable to all; that would deal with irrational states of being and understanding'. ${ }^{6}$ It is not unreasonable to suggest a connection between Rihm's title and Nattiez' concept of sound as signifier. ${ }^{7}$ Rihm has allied some of the ideas of his teacher Stockhausen to theoretical aspects ofArtaud's work, thereby creating a sense of the theatrical within his own music.

A programme note, written after the composition of the first three works in the cycle and before the fourth was completed, describes each work as a 'free-standing part of a kind of "work in 'progress' ('[...]' "selbständige Teile einer Art 'work in progress'"), written 'as hieroglyphs, cuneiform scripts, strange signs - but just signs in sound, script in sound, absolute music, no histories. ${ }^{18}$ These works were written to be

5 'In Sub-Kontur, ist es der Typus des Melodie-Adagios, einer Chiffre [...]' ('in Sub-Kontur it is the type of "melody Adagio", a cipher ...'), in, Rihm, Ausgesprochen, Vol. II, p. 298. Second symphony: "[...]" zudem eine Chiffre für symphonischen Tonfall' ('in addition a cipher/sign for symphonic intonation'), in, Rihm, Ausgesprochen, Vol. II, p. 300. However, the exact significance of 'Chiffre' for Rihm in both of these two references is not clear, with regard to what the actual 'cipher' is: in the programme note for the CD of Chiffre IV (see note 23) he says ingenuously, Chiffre ist '[...]' eine Chiffre!. We should also note that in his 1985 article on the Chiffre cycle to that point, entitled Werk and Werkzyklus, Rudolf Frisius quotes from Rihm's commentary at the premiere of Chiffre VI on 16 April 1985 (in Musiktexte 11,1985, p. 17): 'Chiffre ist ein so vieldeutiges Wort: Es heißt Zeichen, es heißt Zahl "[...]" Es sind Chiffren, die man dechiffrieren kann - nicht muß. Die können auch stehen bleiben. Eine Zeichensprache. Man kann sie auch verstehen aus dem Bewegungsimpuls '[...]' (Chiffre is such an ambiguous word: it means sign, it means number. There are 'Chiffres' that one can decipher - but it is not essential. They can also remain as they are. A sign language. One can also understand them as coming out of the movement impulse). Rihm's use of Zeichen is discussed later. Rihm's linguistic register can be particularly difficult to interpret and I am extremely grateful to Ulrich Mosch at the Sacher Foundation who helped me a great deal in the translation of the German texts, but, any errors are my responsibility! Since there is this difficulty with the text I decided to retain Rihm's original with my translation in all cases to allow other scholars quick access to the texts to which I have referred.

6 I have borrowed the phrase from Edward Isser's internet paper The Semiotics of Acting: from Hieroglyphs to Ideograms (http://www.holycross.edu/departments/eisser/semiotics.html; accessed 15 March 2006) where he discusses the significance of Artaud. For further discussion in English of Rihm and Artaud see Williams, Alistair. 'Voices of the Other: Wolfgang Rihm's Music Drama Die Eroberung von Mexico'. in Journal of the Royal Musical Association, vol. 129 part 2, 2004, pp. 240-271, particularly pp. 242-3, and p. 264ff.

7 See Jean-Jacques Nattiez, Music and Discourse, trans. Carolyn Abbate, (Princeton: Princeton University 1990), especially pp. 1-6.

8 Rihm, Ausgesprochen, Vol. II, p. 343: '[...]' wie Hieroglyphen, Keilschriften, fremde Zeichen, aber eben Zeichen im Klang. Schrift im Klang, absolute Musik, keine Geschichten.' Rihm's reference to hieroglyphs may be a reference to the work of Meyerhold who 'believed that Western theatre needed to establish a series of clearly discernible and decipherable hieroglyphic signs.' (Isser, The Semiotics of Acting; as footnote 6). 
'free '[...]' from progress and process direction' ('frei '[...]' von Verlaufs- und Verarbeitungsvorgaben'), collections of moments of singular events in sound (Einzelereignisse) not in imitation of his teacher Stockhausen, nor in homage, but drawing on the older composer'sconcept.

Rihm's music of the 1980s habitually balances activity with stasis. This is not done in a pre-planned way and the analyst looks in vain for traditional generative processes. Nevertheless his music relies for its effect on the manipulation of the dramatic: the gesture as signifier. These gestures are primarily chordal or motivic which operate within a static framework provided by generally invariant tempo and constant metre.

The significance of Rihm's programme notes for the Chiffre cycle will be explored later but in order to understand better the compositional imperatives at work in the cycle it is helpful to utilize some of the 'sound words' he uses when writing about the works. These words act as verbal signifiers for the musical processes and it is therefore important to be able to translate them into the musical gestures to which they relate $^{9}$ as a basis for the analysis of Chiffre VI which follows.

\title{
KLANGRAUM (SOUNDSPACE)
}

\author{
Chiffre [1] \\ 'As if the attack writes itself into the sound body, so that it describes the \\ empty sound space..$^{10}$
}

The concept of Klangraum is a key component in Rihm's compositional thinking and this quotation from the Chiffre [I] programme note provides a metaphor for the 'Soundspace'. It suggests a certain aggressive damaging of the virgin canvas and evokes the graphic arts in its effect. It also suggests particular sonic qualities which result from the idea of 'attack'. Klangraum can be defined by a number of different attributes but most often by the chordal components and/or by characteristics of the instrumentation. In the Chiffre works three elements dominate the pitch components of the Klangraum: single chord or unison/octaves either sustained or repeated rhythmically, sometimes creating 'focus pitches'; brief motivic idea(s), often expressed as arabesques; short chord sequences. While there is no sense of progression through these components or within the chordal strata, each of the elements have recurring characteristics influencing continuity across each work. The repeated pitches do not serve a structural function except where they are being utilised as focus pitches (a typical use will be found in Table 3, as labelled), and

\footnotetext{
$9 \quad$ Within the programme notes for the Chiffre series and Bild one finds the following 'soundwords': Klang -körper; -körperteile; -raum; -objekten; -zeichen (or Zeichen im Klang); -schrift (or Schrift im Klang); -plastik; -texte; -farben; -aktion; -hiebe; ein neuer, anderer Klang; Klavierklang; (bewegter Klang). The same preoccupation can also be seen in the article reprinted in Wolfgang Rihm, Offene Enden ed. Ulrich Mosch (Munich, Vienna: Carl Hanser Verlag 2002), p. 129.

10 Chiffre [I] programme note in Rihm, Ausgesprochen, Vol. II, p. 331: 'Als ob seine Attacke die Schrift erst in den Klangkörper treibt, den leeren Klangraum erst beschreibt.'
} 
neither do the motivic/arabesque ideas function structurally in a traditional formal manner although they undoubtedly contribute to the sense of continuity within the cycle.

\section{Pitch [chordal strata]}

It is, above all, through the manipulation of the chordal strata that Rihm seeks a structural coherence for this series of works and consequently in the works of the Chiffre cycle it is the chordal elements which have the greatest importance within the pitch domain of the Klangraum. One of the most significant of the chord types, found throughout, certainly originated in the chamber opera Jakob Lenz (1977-8). In his programme note for the opera Rihm identifies this chord as 'the sound underlying the whole work', ${ }^{11}$ and the same chord, allowing for changes in disposition and inversion, is a 'generative pole' for the first of the Chiffre works, as will be seen in Ex. 1b. It is possible that Rihm's use of this particular chordal structure simply stems from a desire to retain connections between works.

The phrase 'generativer Pol' was first used in the programme note for Chiffre [I], written in 1983 'the short piece could be a generative pole of a bigger piece' ('das kurze Stück könnte der generative Pol eines größeren Stückes sein') and again in the programme notes for Gebild in the same year. It was subsequently highlighted in an interview between Rihm and Peter Sloterdijk as a useful way of describing the processes underlying the works of the $1980 \mathrm{~s}^{12}$ It is a term I shall use throughout the article since it avoids the notion of development but at the same time implies a sense of progression.

A repoled idea essentially transforms a preceding idea while retaining the essence of that idea in some form. What is more, Rihm relies on his listeners to perceive this connection since he has created a strong sense of 'organic' growth within each work and across works in the cycle. I discuss this further in due course in the section on A Sound Transforms its Predecessor. A generative pole can consist of a thematic motif, (such as the opening motif of the fourth string quartet) which is subsequently placed in different contexts, often rhythmic, where, in essence, the pitch content remains invariant, and largely constant, while the rhythmic profile is subject to great variation. It can be designated as a pole because it is rooted in a central, usually pitch-based, idea around which the music turns. Such a situation occurs when, for example, part of a chord stays constant while the rest of the chord varies round it, accruing or losing density. So, the Lenz chord in Chiffre [I] retains its identity through the cycle as a pole or root, but has no tonal implication.

$11 \quad$ Rihm, Ausgesprochen, Vol. II, pp. 314-5.

12 Peter Sloterdijk, Der generative Pol: Wolfgang Rihm in Gespräch mit Peter Sloterdijk (7.11.1988), in Österreichische Musikzeitschrift, XLIV 6, (June 1989), p. 281ff, and see Rihm, Ausgesprochen Vol. II, pp. 327-8. However it is a term that he uses in his own poetics within the article Musikalische Freiheit, for which see Rihm, Ausgespochen Vol. II, pp. 23-39. As a concept it is therefore clearly embedded in the context of his own writing. The term contains also the notion that the listener can take an active part in the process. This has led to other related sets of works where the concept is expressed in the title as for example in Pol - Kolchis - Nucleus dating from 1991/96. 
Ex. 1a: Rihm, Jacob Lenz, generative chord

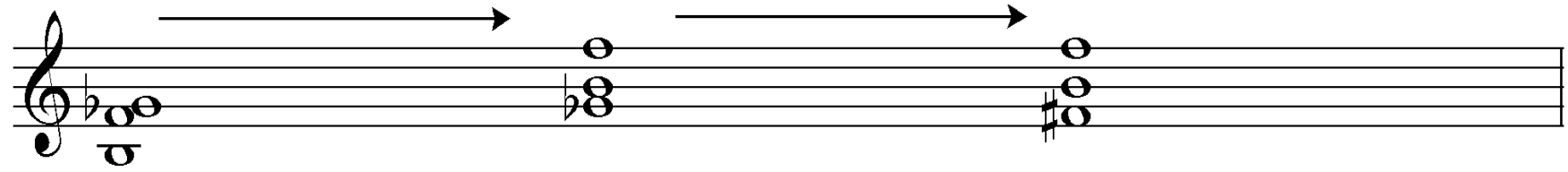

In this first work of the cycle the Klangraum is defined in various ways through chordal and motivic disposition, and an examination of these gives an insight into Rihm's compositional methodology for the cycle as a whole. Ex. 1b shows the chord sequence of the first 27 bars of Chiffre [I] (up to the point where a new motivic idea enters), ${ }^{13}$ and these are labelled (a) to (l).

Ex. 1b: Chiffre [I] chord sequence bb. 1-27
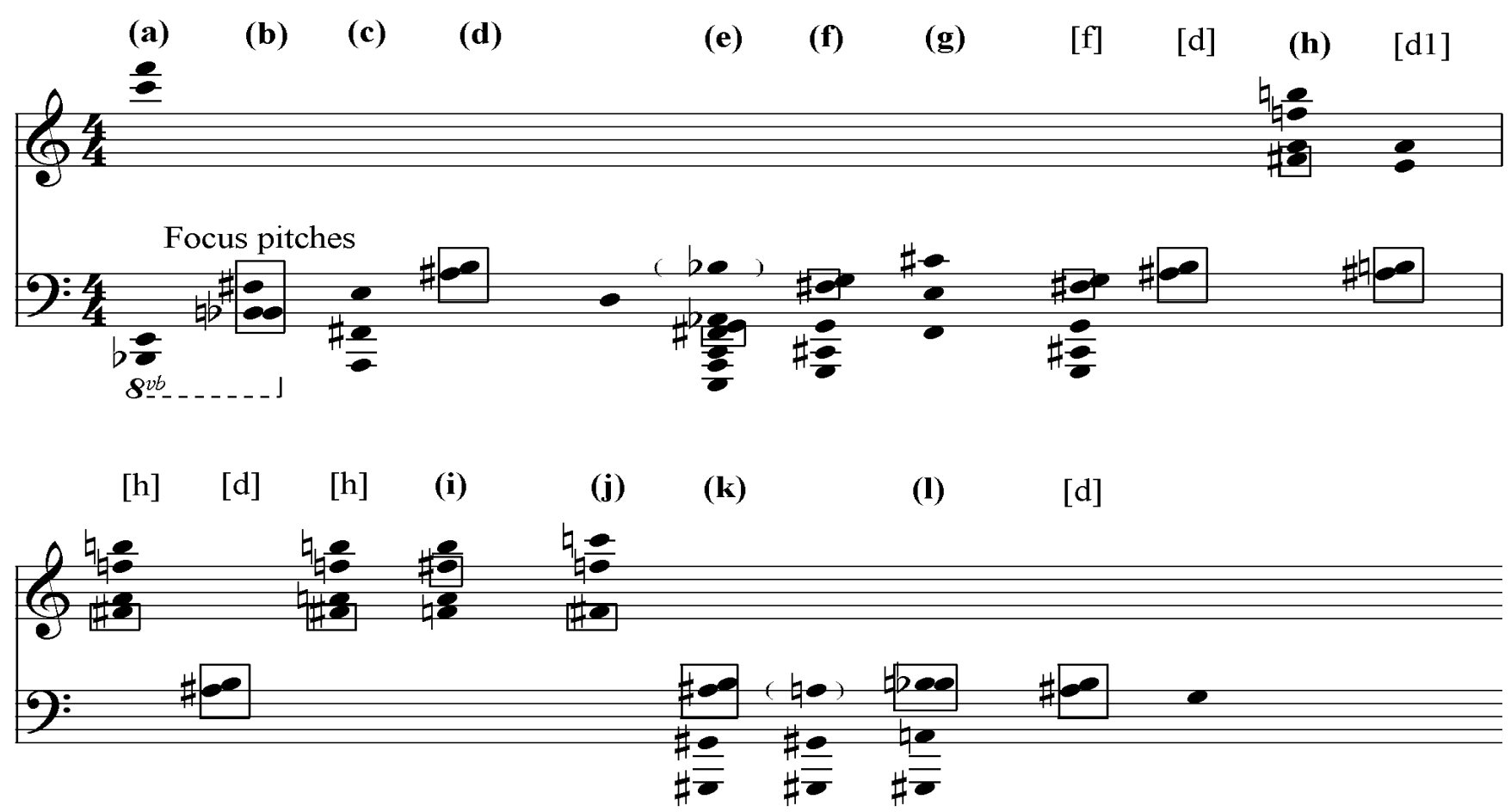

Most of the chords can be seen to contain components of perfect fourths and fifths, the tritone and, occasionally, the augmented $5^{\text {th }}$. The other principal component of some chords is the trichord cluster [in (e) and (1)] and by extension, the pervasive $B-A \#$ dyad. Only two chords have other pitch combinations and the most important of these is chord(e) which includes a low A minor triad. This chord is distinguished from the others at first hearing by being repeated across a whole bar on celli and bassi, mostly in semiquavers and marked col legno batt. with sharp accents on each note, at fff dynamic. This chord, in various elaborations, recurs throughout the cycle and is an element contributing to its unity. From the

13 The score is published by Universal Edition as a copy of Rihm's autograph score. As such it is entitled simply Chiffre suggesting that, initially at any rate, while the work was intended to generate more works these were not originally thought of as bearing the same title. The formal construction of Chiffre II really precluded any other title, other than one which embodied the word at least, since as I explain later, Chiffre lies at the heart of Chiffre II. For clarity I refer to the first Chiffre as Chiffre [I]. 
available sketch material (see Appendix) it appears that the chord sequence $(\mathrm{d})(\mathrm{h})(\mathrm{d} 1)$ was one of the initial ideas, if not the generating idea for the work. The pitch content of (h) comprises $F, B, F \#, A$, exactly the Lenz chord with added $A$, while $\left(\mathrm{d}^{1}\right)$ is an inversion of the same chord based on $A$, (and with the addition of $B)$.

This chordal sequence leads directly into the first structurally significant shift of character in the piece - a short fanfare-like motif, which, as Ex. 2a and $2 \mathrm{~b}$ show, is simply the pitch content of chord (i) transposed down a perfect $5^{\text {th }}$ (T5). ${ }^{14}$ Although this motif occurs in the sketch material on the same page as the chord sequence $(d)(h)(d)$, there is no indication there of an exploited relationship between them.

Ex. 2a Chiffre [1] generative chord [(i) in Ex. 1b]

\section{Ex. $2 \mathrm{a}$}

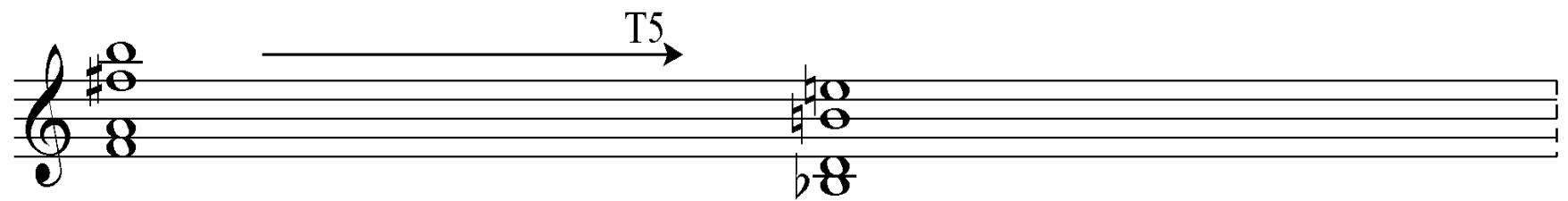

\section{Ex. 2b Chiffre [1 Motif 1 bb.31-2}

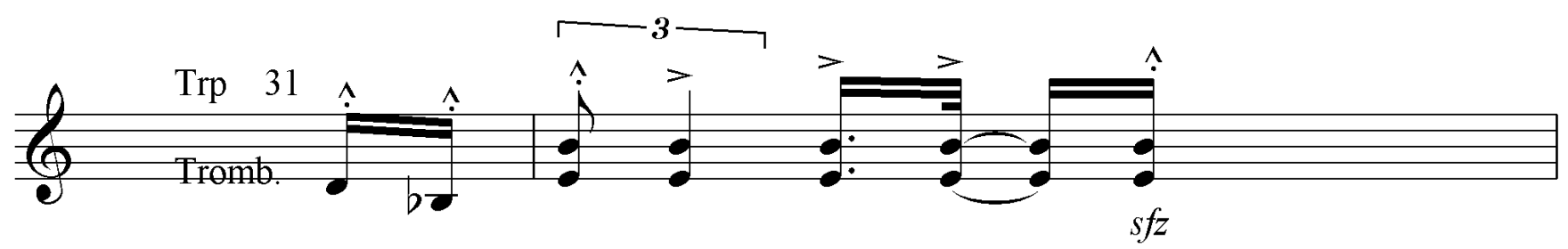

Motif $1,{ }^{15}$ transferred to piano, leads directly into Motif 2, the only other recurrent non-chordal thematic entity in the work. Although conceived as a unit, this new motif essentially splits into two parts (Ex. 3). The motif builds upon the interval of a major $3^{\text {rd }}$ borrowed, and hence repoled, from Motif 1 although the layout of the sketches for the work suggests that Motif 2 may have been written first.

14 Chord (i) and therefore potentially chord (h) can be construed as having been derived (either consciously or unconsciously) containing the key elements of the opening chord of Schoenberg's Six Little Piano Pieces Op.19/6, and given Rihm's high regard for Schoenberg's atonal works, such an association is not unlikely.

15 Frisius views the pitch $G$ (see Example1b last pitch) as the start of the motif, or as he terms it, Unison-melody, in, Frisius, 2004, pp. 85-6. My interpretation is derived from the sketches and Frisius does not appear to have used these. I would therefore derive bb. 30-1, pitches $G, D, C \#$ as a melodic expression of the Lenz chord. 
Ex 3a: Chiffre [I] Motif 2 (taken from original sketch form)

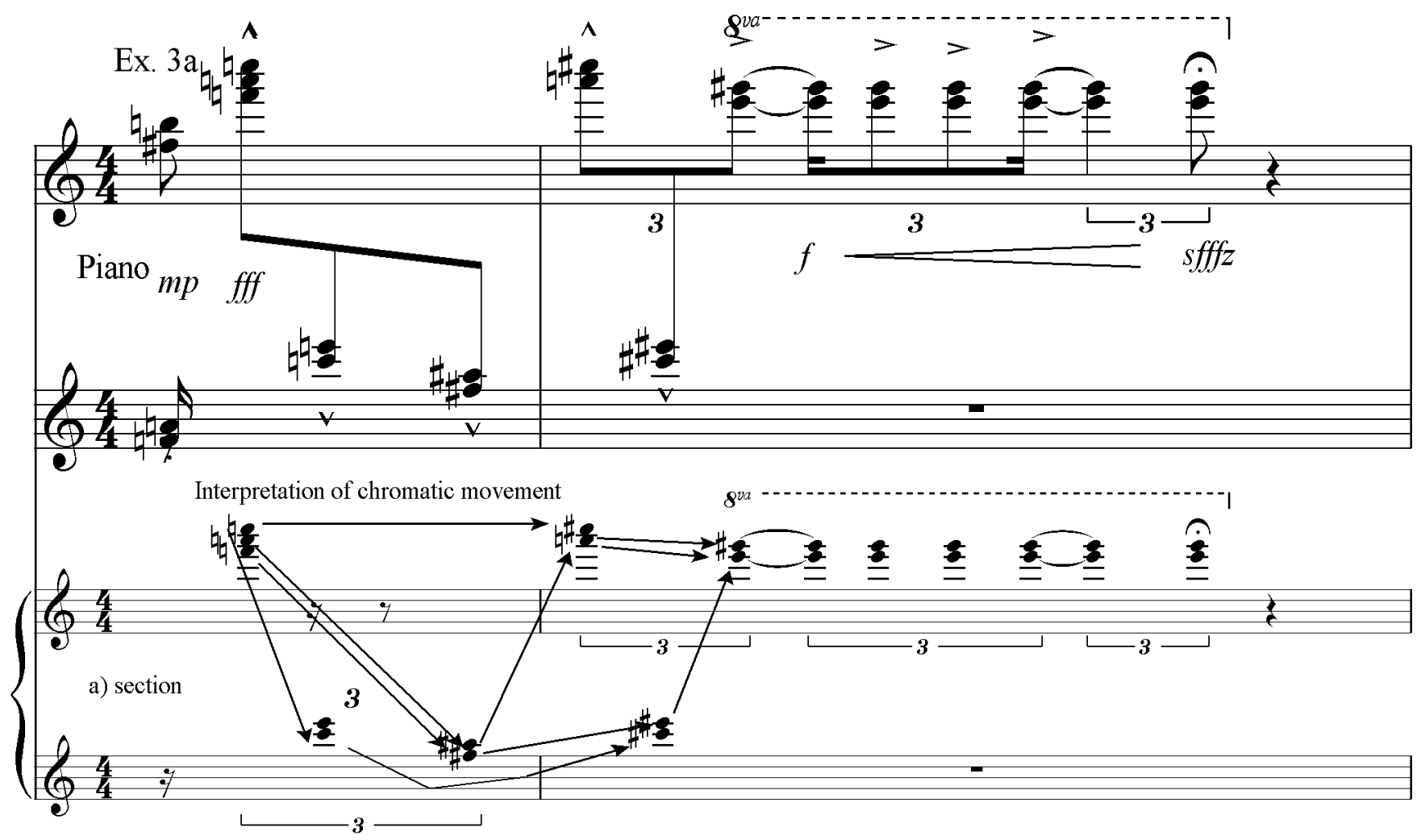

Ex. 3b: Chifre [I] Motif 2 (as at b. 37)

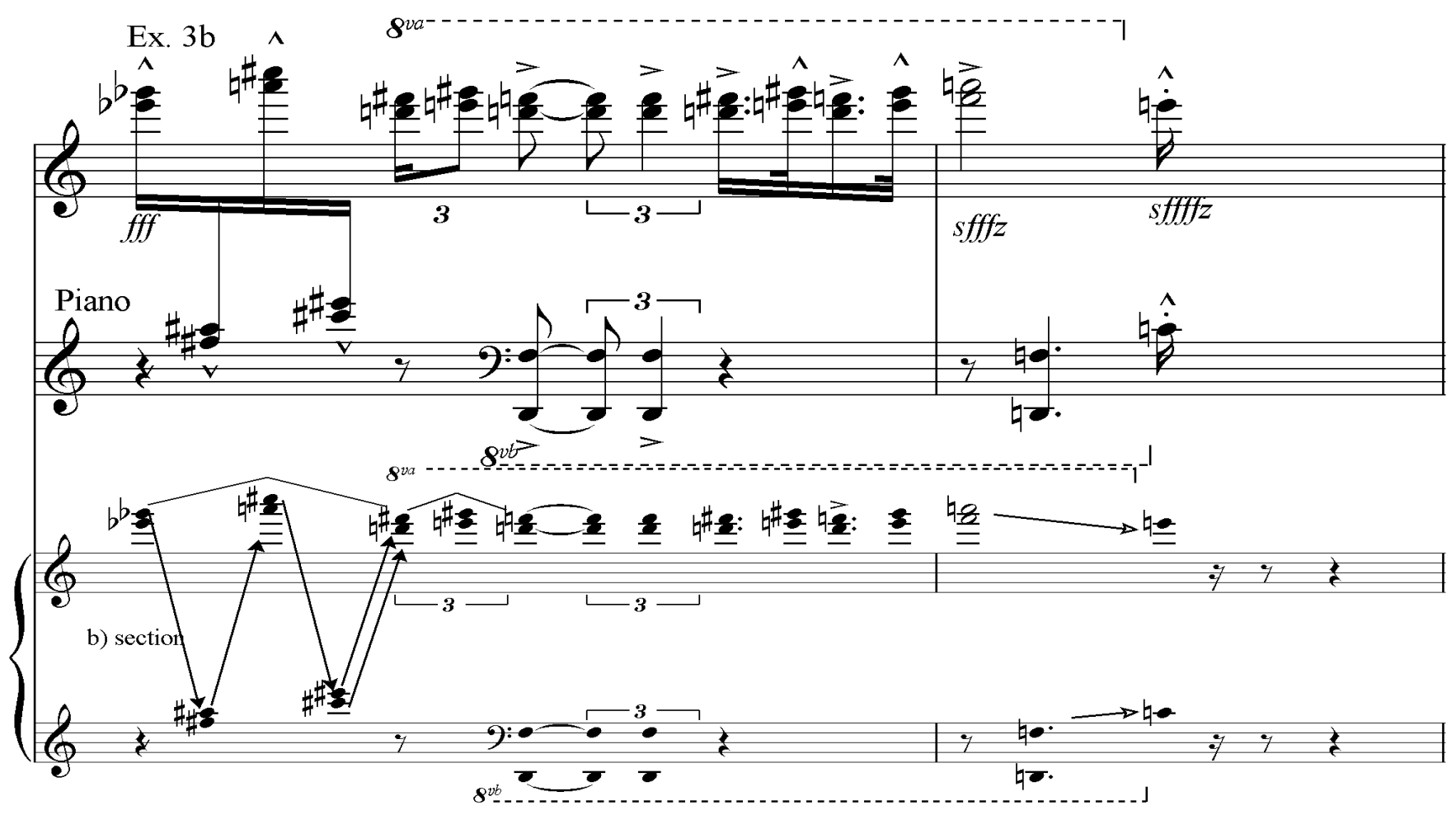


The (a) section of Motif 2 is derived from the juxtaposition of two dyads, moving chromatically in contrary motion, whereas the (b) section of the motif reuses the dyads created as generative entities. Despite having been originally conceived with varying time signatures in its final form this motif is simply integrated into the constant four-crotchet metre of the whole work: Rihm's use of a largely static time signature will be explored in due course. In the compositional sequence it is significant that the first dyad $f^{3}, a^{3}$ (first bar left hand Ex. 3a) was added later to the sketch since this links the opening pitches of the motif, in the upper and lower parts respectively, directly to the generating chord sequence $(d)(h)\left(d^{1}\right)$.

My reading of this work is rather different from that of Rudolf Frisius who identifies five main sections but, for the most part, no further sub-sections of these. He divides these into: bb. $1-27 ; 27-75$; $75-$ $87 / 8 ; 87 / 8-108 / 9 ; 108 / 9-173 ; 174-76$ (close) and his subsequent analysis is based on elementary aural events (Hörereignisse) and larger formal units (Abschnitte) which interact - sound units which tend to be shorter than those I am proposing. For Frisius the importance of Chiffre [I] is that it points towards a development in Rihm's thinking in differentiating between structure and form (das zwischen Struktur und Form differenziert). ${ }^{16}$

Frisius views the first motif as an extended 'melodic' idea starting from b. 27 and ending with the open fifth $e^{1}, b^{1}$ at b. 32 (in its most condensed form this is bb. 27-29), which he then relates to b. $77 \rightarrow$ in what is effectively a repoling of the dyad $D, C \#$ (Frisius does not use the term 'repoling' to articulate this). However, I have read this as a structural subsection of a larger unit as will be seen in Table 1 (sections $1 \mathrm{~b}$ and $\left.1 b^{1}\right)$.

After Chiffre II, in which they reappear, neither of these motifs recur again, ${ }^{17}$ although some of the chords are 'repoled' with their densities increasing from Chiffre III to Chiffre VI in order to reach a climax point on a 12-note chord in Chiffre VI, the only work in the cycle not to include the piano (Ex.4 and see also Ex. 9b).

16 Rudolf Frisius, Wandlungen des musikalischen Denkens über Form und Struktur im Spiegel der Musik von Wolfgang Rihm, Überlegungen am Beispiel von Chiffre I, in, Wolfgang Rihm Musik - Konzepte: Sonderband X11/2004, ed. Ulrich Tadday, (München: Richard Boorbeg Verlag, 2004), pp. 75-92. Frisius has also written on the Chiffre series in Zum Chiffre Zyklus, in, Wolfgang Rihm: Komponistenportrait, programme booklet of the $38^{\text {th }}$ Berliner Festwochen 1988 Berlin: Berliner Festwochen 1988), pp. 13-19, and in Werk und Werkzyklus, in, Musiktexte 11, 1985, pp. 17-26. In fact there are very few musical ideas in the cycle which would properly be classed as motivic if the principal criterion of a motif is that it should have some structural significance. 
Ex. 4: Principal chords Chiffre III - VI

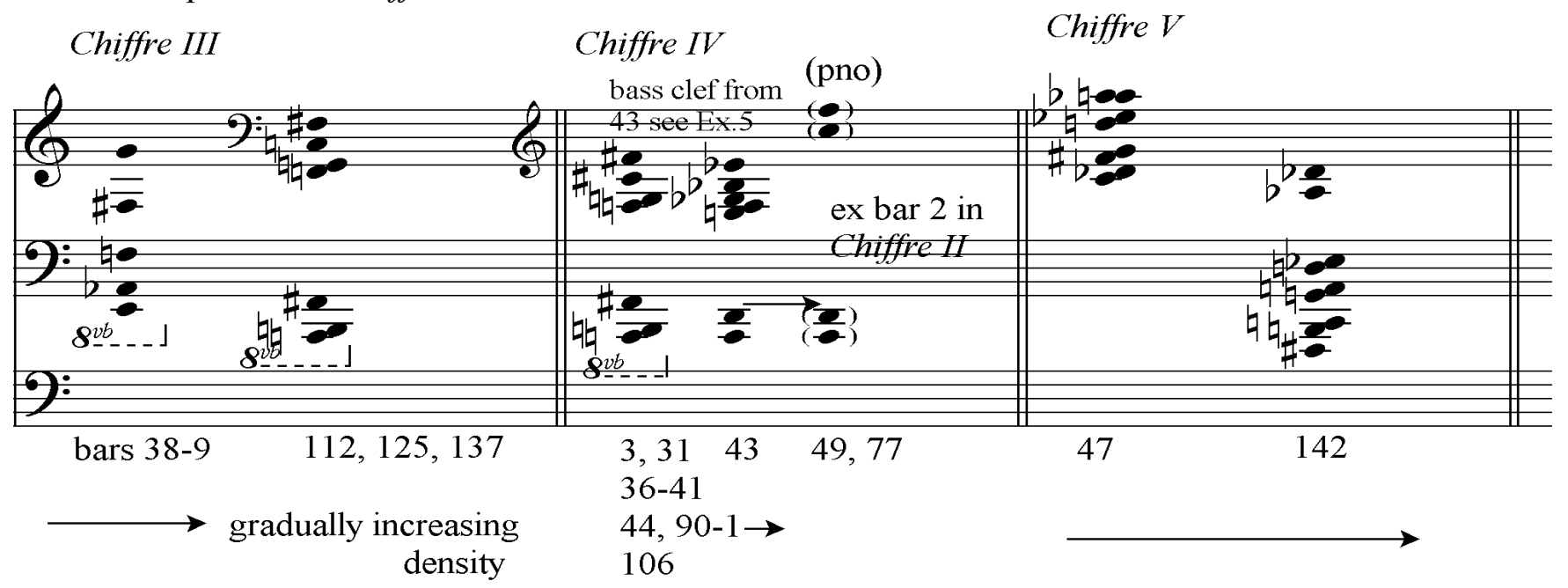

Chiffre VI

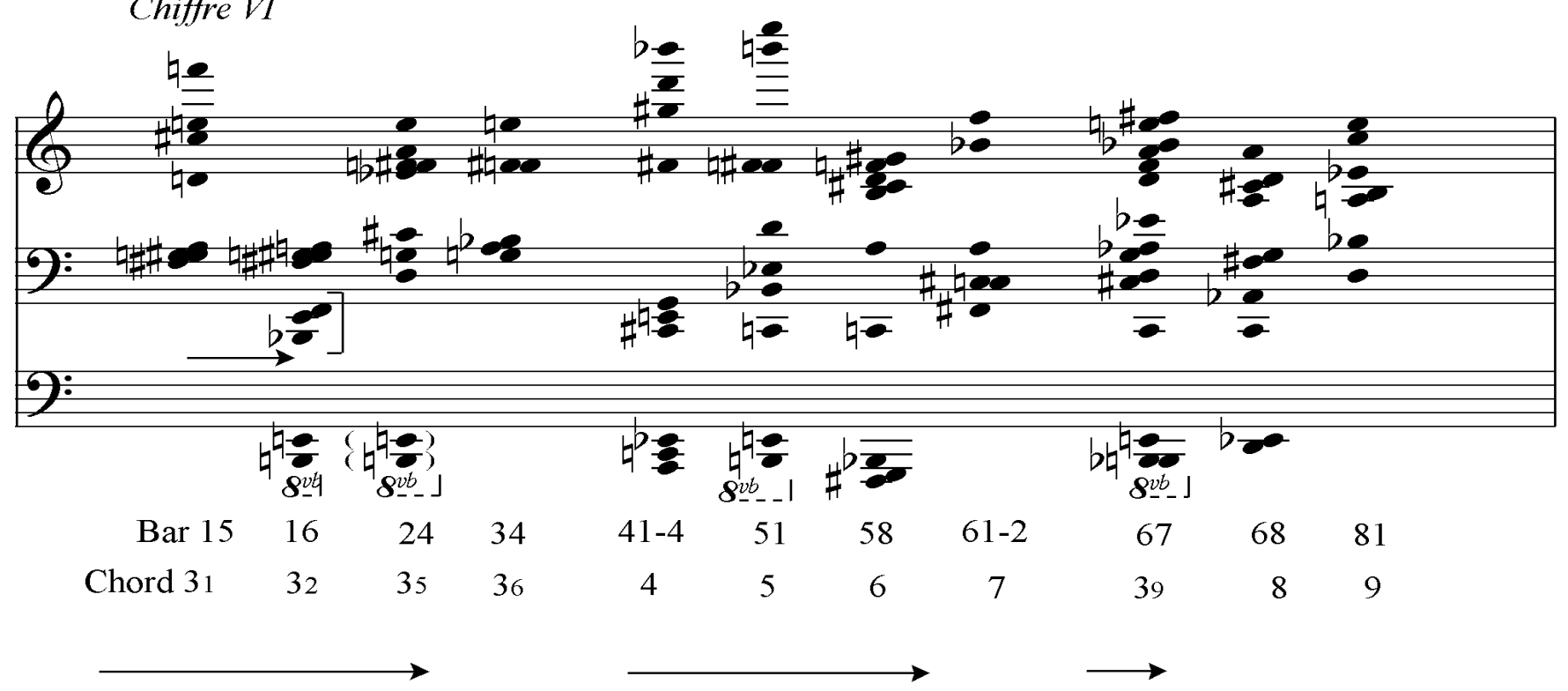

It might seem that, far from being an active component of the Klangraum, the chordal elements are little more than a background against which the piano is foregrounded. That this was not Rihm's conception is shown by this statement concerning Chiffre [I]: So in that way both are unreadable but together a signthe piano sound describes the instruments and vice versa. ${ }^{18}$

\section{Instrumentation}

Notwithstanding the manipulation of pitch components, it could be argued that it is primarily through instrumentation that Rihm delineates Klangraum in this cycle: the most obvious and audible connections throughout the works are made by means of instrumentation. Clearly the exigencies of performance and

18 Chiffre [I] programme note: Rihm, Ausgesprochen Vol. II, p. 328: 'So voneinander beschrieben sind beide Klavierklang und Instrumente - unlesbar, aber zusammen: ein Zeichen.' 
economy played a part here, but within these constraints there are constant features which need to be understood. The instrumentation for each work (excluding detail of individual percussion instruments), is given in the Appendix, and from this it is clear that there are timbral connections between compositions in the cycle. Thus Chiffre VIII reflects Chiffre [I], except that the trumpet is replaced by horn, and the clarinet and bassoon are reassigned to bass clarinet and contra-bassoon respectively. The bass clarinet creates a link between Chiffre [I] and Chiffre IV since it has a role in both, but it makes a more significant link between Chiffre III and Chiffre VI which both specifically feature the bass clarinet. The contra-bassoon in Chiffre VIII links this work with Chiffre II and Chiffre III but above all with Chiffre VI.

Rihm's preference for bass register is evident in his use of other low pitched instruments in addition to those already mentioned, namely, two cellos and double bass in Chiffre [I], III, V, VII and VIII, and bass trumpet in III, $V$ and VII. These bass instruments serve in part to balance the bass register of the piano. However, rather fewer instruments counterbalance the top end of the piano, notwithstanding the fact that the highest instrumental registers can only be achieved by a small number of instruments. Thus we find only two violins in Chiffre II, VI and VII, piccolo in Chiffre II, V and VII, Eb clarinet in II, V and VI and high trumpet in $I I$ and Bild. Ex. 4 demonstrates how this preference for lower sounds affects the timbral disposition of the structurally important chords in the middle works of the cycle, but it is an idea that finds expression in many of his works. Rihm's love of deep sounds is revealed in this extract from an interview where he speaks about making the electronic tape for Séraphin:

There are wonderful possibilities to make sounds really, really, really deep, deep. That deep and not longer: you know the problem you make something deep and it becomes longer and longer [and] I have wonderful chords of four bass trombones and four tubas from Étude pour Séraphin. I took [original 'take'] that and we manipulate[d] them into the abyss. It sounds wonderful ' $[\ldots]^{19}$

The piano plays a central role in eight of the nine works in the cycle. In Chiffre [I] it writes upon the Klangraum created by the other seven instruments ${ }^{20}$ and continues to have a dominant role in the other works in the cycle, except for Chiffre VI where its absence is registered in the programme note: 'Wo Klavier? Tot? Nix?' (Where piano? Dead? Nothing?). This is symbolic: the piano has apparently been

19 Wolfgang Rihm, Interview with the author, 18 Nov 2000 Huddersfield Contemporary Music Festival, currently in press as McGregor Richard, Hunting and Forms: An Interview with Wolfgang Rihm, in Contemporary Music: Theoretical and Philosophical Perspectives, ed. Max Paddison and Iréne Deliège, Aldershot: Ashgate, expected 2007. The interview was conducted in English although Rihm much prefers to discuss such matters in his native tongue. Chiffre [I] second programme note: see Rihm, Ausgesprochen Vol. II, p. 331. See footnote 10. In his programme note for Chiffre [I] Rihm describes the instruments as Resonanzraum, that is to say, a resonating space/resonator for the piano. The piano etches itself onto the instrument space (hence Rihm's use of Keilschriften), it leaves traces on the surface of the other, the surface is 'hurt'. Like many of his images this evokes techniques associated with Art, and in this case Graphic Art. 
silenced and is therefore absent but, paradoxically, it also makes its presence felt in its absence through its gestures being taken over by the other instruments. Although it is normally treated like a solo instrument ('Das Klavier ist wie ein Soloinstrument behandelt') $)^{21}$ these are in no way concerti. The piano is certainly a protagonist, but not a heroic one. In Chiffre [I] and II it rarely contributes to the surrounding chordal texture. Instead, it defines the space in which the other parts operate since it plays either just the highest $A$ on the piano or a trichord cluster $f x^{4}, g \#^{4}, a^{4}$ in highest register and a trichord cluster $C^{3}, B b^{3}, A^{3}$ in lowest. These chords are articulated through rapid repeating rhythms akin to the writing in Rihm's Klavierstück VII (1980) and hence also like some of Stockhausen's piano writing from which it no doubt derives. Subsequently the piano writes in this space itself and from his programme notes ${ }^{22}$ it is clear that we are expected to perceive the interaction of instruments and piano as central to the cycle, and that the symbolism of the 'vanquished' piano in Chiffre VI is primarily metaphorical: the piano's absence is analogous to the musical silences - particularly of Chiffre II - which Rihm says 'must be beaten' ('geschlagen werden muß') and 'must be defeated' ('besiegt werden muß') but silence 'out of which the sounds leap' ('Schweigen, aus dem Klänge herausschlagen werden'), and sounds which are 'collapsed in the silence' ('Klänge, in die Schweigen hineinbricht').

It is harder to define the relationship of the unpitched percussion to the whole, in that their sounds do not generally relate directly to the piano or to the other instruments. However Rihm's percussion writing in the Chiffre cycle is entirely characteristic of his use of such instruments in the majority of his scores. He generally employs traditional instruments cast in their usual role of reinforcing texture and dynamic. Percussion is used in Chiffre II, III, V and VII, that is, in works having more than 12 players. Although they are absent in Chiffre VIII, the instrumental body sounds in the closing bars of the work are probably a suggestion of the role of percussion in the other works of the cycle. From one sketch of the Chiffre II it appears that a percussion part was initially considered as the link between Chiffre II and Chiffre III.

One can also infer from the sketches that Rihm's original conception of the cycle needed much more limited forces - piano with perhaps two or three instruments only - and that Chiffre $V$ was to be the final work where all the instruments used in the cycle would play together. This idea was superseded at an early stage of work on Chiffre [I] although when Rihm says of Chiffre IV that it is 'only for three players but meant as an orchestra (nur drei Spieler, aber als Orchester gedacht)', ${ }^{23}$ or, as it says in the score, ' $a$ piece for a little orchestra to play' ('[...]' ein Stück für kleines Orchester zu spielen') he is probably referring back to his original idea.

\footnotetext{
$21 \quad$ Rihm, Ausgesprochen Vol. II, p. 331.

22 Rihm, Ausgesprochen Vol. II, p. 331 (programme note on Chiffre [I] II III), and p. 344 (programme note on 'Silence to Be Beaten' Chiffre II).

23 Rihm, Ausgesprochen Vol. II, p. 344.
} 


\section{Metre and Tempo}

Although dynamic, or perhaps dramatic, processes operate in the Klangraum through the chordal/motivic and instrumental aspects, these are constrained and controlled by two elements which, for the most part, remain static: metre and tempo.

The default metre (as in many of Rihm's works) for all the Chiffre cycle is four crotchet beats to a bar, and rare exceptions to this either mark a significant structural point, as is the case at Fig. $\mathrm{N}$ in Chiffre II (see Table 2), or, are used simply to accommodate a localised shift in the rhythmic structure. The latter usage is the more common, and typical examples are: in Chiffre $V$, the 4 beat metre is interrupted at bb. $20-3$ by 3 bars of $3 / 4$ and one bar of $3 / 8$ which highlights a rare 7:6 division of the beat in the piano, clarinet and bass parts; in Chiffre III a change to 5/4 accommodates the whole of a chromatic flourish in bass clarinet and celli, and the $3 / 8$ which occurs four bars later partly accommodates the instrumental flourish and partly articulates cross-beat syncopation. Thus by its very rarity metre change serves to emphasize dramatic tension at the local rather than at the structural levd.

Rihm's use of tempo markings is analogous to his treatment of metre. In most of these works there is a controlling tempo, often within the range crotchet $=60-108$. Variations from the control tempo function in much the same way as changes in metre but only very rarely does a tempo change coincide with a change of metre, and then usually to mark out some very specific detail: the final 'cadential' bars of Chiffre IV or the introduction of a new syncopated feature at b. 98 of Chiffre III are perhaps the only really significant examples in the whole cycle. Tempo markings rarely exceed crotchet $=100$, except for the opening of Chiffre II, and in that work this is effectively the control tempo for the work, even though it only finally establishes itself some way into the piece, at Fig. P, at which point the silences begin to assume greater importance, subsequently leading directly into the second repeat from Chiffre [I] (see Table 2).

The slowest tempo used in the cycle is crotchet $=40$ and although rare, it can be an important structural marker: it is the tempo which leads into the first repeat of Chiffre [I] within Chiffre II, and it is the control tempo of Chiffre VIII. Finally, except for Chiffre [I] and Chiffre VII each work returns to its opening tempo, even Chiffre III, which begins at crotchet $=88$ and ends crotchet $=80$ but has an accelerando in the last three bars. As with metre these relatively rare tempo changes have a local rather than a structural effect. 


\section{KLANGZEICHEN (Soundsigns)}

In the Chiffre series, as indeed in all Rihm's music, fundamental components are the Klangzeichen 'Soundsigns'. While there might be a number of ways of interpreting what Rihm means by this word, undoubtedly the most significant is as a means of defining articulation: it is not just the pitch or the chord which is important in the musical context but exactly how it is to be played. The individuality of a sound and the juxtaposition of discrete sounds (i.e Einzelereignis = moment of sound) determine the direction and character of each work. Rihm's search for the 'flavour of the special sound ${ }^{24}$ of a musical event is obsessive.

Virtually every pitch has some kind of articulation specified, and in a sense the music moves from one articulation to the next, with varied articulation superseding pitch imitation between parts as the primary musical feature at some points. For the purposes of this discussion I include within the term 'articulation' those dynamics which are applied to an individual pitch to affect the way it is played (Rihm does use sectional dynamics, but not as a common practice). This trait might well be a throwback to his serial period but in these works there is no sense in which articulation or dynamics are hierarchically ordered.

Ex. 5: Chiffre IV bb 43-4

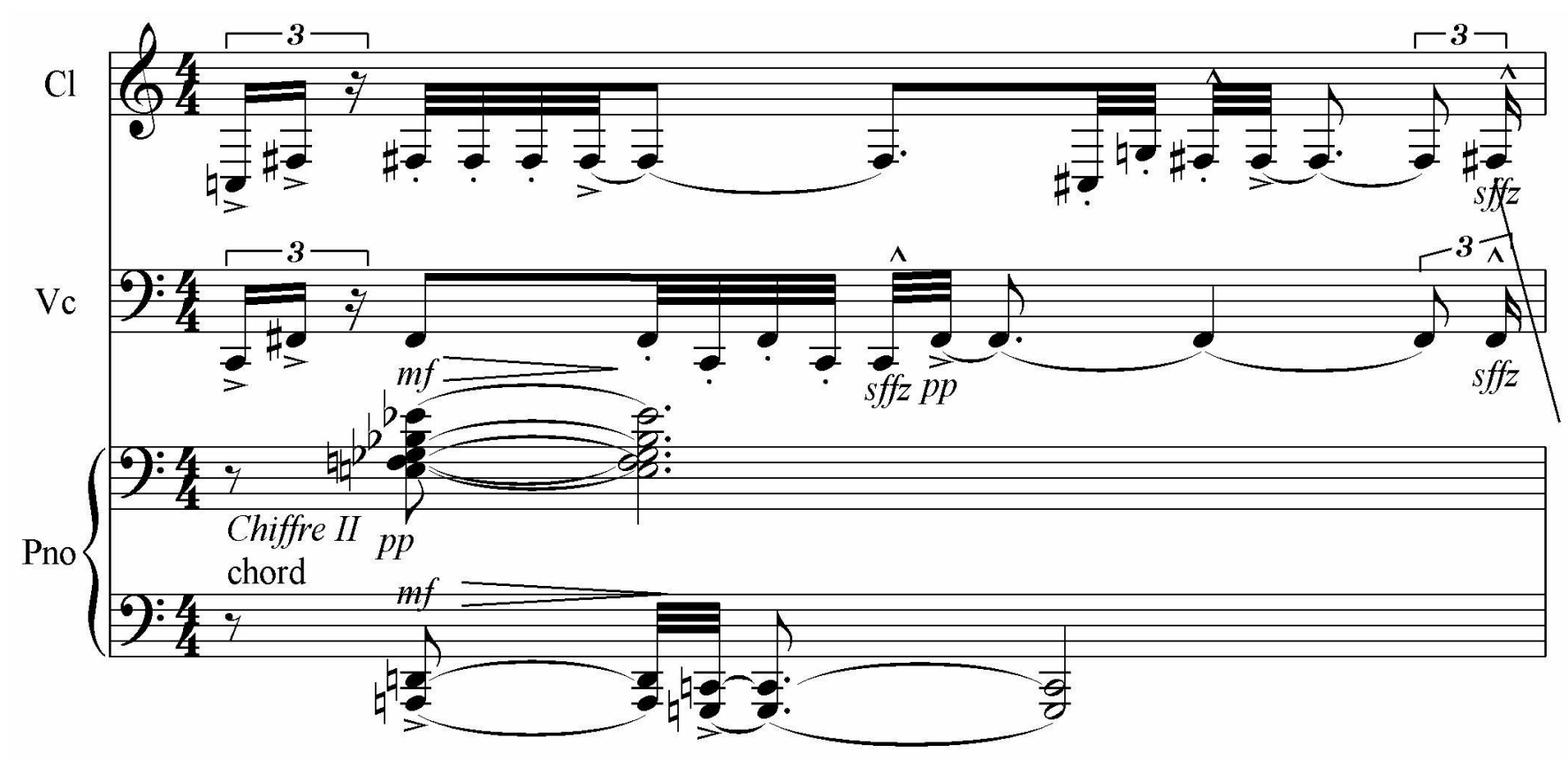

24 McGregor, Hunting and Forms: An Interview with Wolfgang Rihm op. cit. 


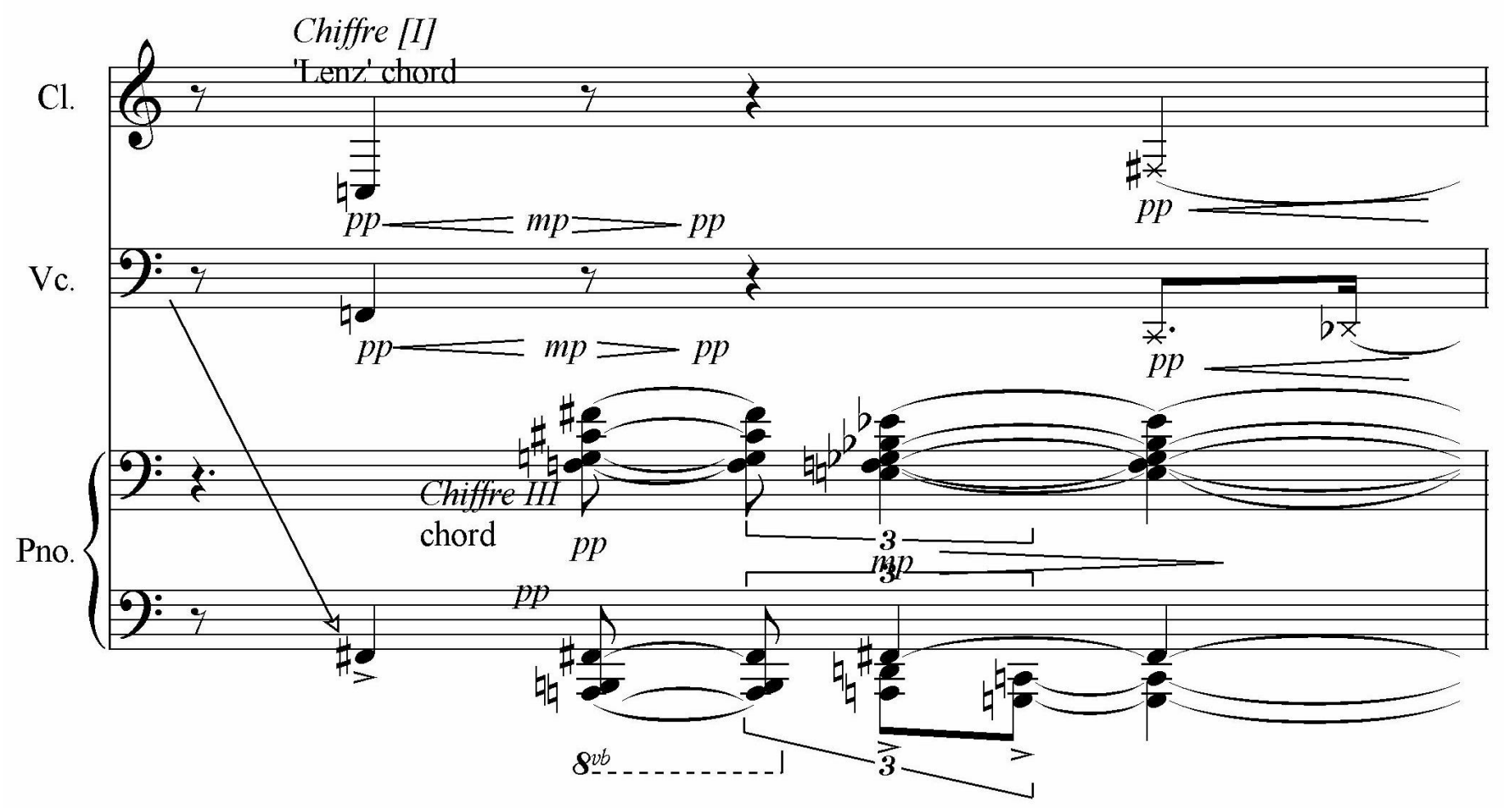

This short example illustrates a number of inter-related elements. The detailed articulation directions serve to draw attention to each of the musical entities in different ways. The piano chord at b. 43 , which is a repoled chord from Chiffre II (in that it is now placed in new context), is given two dynamics, the louder of the two for the left hand dyads which are also accented to draw the ear to the perfect fourths which are counterpointing and interacting with the tritones between the clarinet and cello. ${ }^{25}$ On the other hand, the first chord in b. 44, which has come from Chiffre III, is marked $p p$ matching the dynamic level of the clarinet and cello, possibly to achieve continuity, but the repeat of the chord from b. 43 is given a new dynamic with accents retained in the left hand. The accenting of the $F \#^{1}$ in cello in b. 43 provides a temporary focus pitch confirmed by its transfer to the piano left hand in b. 44 (and also in the move from the first chord of the bar right hand into the second where it is already present as enharmonic $G b$ ). Finally, the clarinet and cello parts have staccato markings and additional dynamics throughout which ensure that no pitch lacks 'purpose' within the texture. A sound sign of prime importance in Rihm's music is silence onto which he ascribes many layers of meaning (see note 22) and it serves to throw the pitch collections into relief. Silences therefore have an active textural and articulative function. The concept of an 'active'

$25 \quad$ The role of fourths and fifths is explored in more detail by Wolfgang Hofer in Triobeschreibung: Rihm, booklet in Wolfgang Rihm, Trios 1969-1994, CD, Kairos 0012092KAI 1999/2000, English translation pp. 16-22: 'Chiffre IV is built on fourth and fifth stratifications. However in the German there is more which has not been translated in the French or English versions (pp. 6, 16 and 23 of the CD programme booklet): Tritonusreibungen bewirken vagierende Kunst des Übergangs zwischen dunklem Grund und schwebenden Stimmen, Echoschatten, Ausklangperioden (Tritonal friction induces a floating art of transitions between the dark ground and suspended voices, echo-shadows, section envelopes). I am grateful to Ulrich Mosch for pointing out that vagierende is probably a reference to Schoenberg's idea of the vagierende Akkord ('indeterminate (or, as Phipps (1985 argues, 'vagrant') chord' first introduced in Schoenberg's Harmonielehre, $1^{\text {st }}$ ed., p.270), while Kunst des Übergangs probably refers to the German subtitle to Adorno's biography of Berg. Ausklangperioden is particularly difficult to render into English, as indeed is the whole sentence, hence I imagine the reason for its omission from the CD translation. I have therefore chosen to keep the translation quite literal. 
silence - silence as signifier - is demonstrated above all in Chiffre II which was originally subtitled Silence to be Beaten ${ }^{26}$ and therefore probably not initially conceived as being related to Chiffre [I]. In his programme note the composer acknowledges that the title is a conscious reference to Varèse: 'Inscription on many general pauses in Varèse scores (Inskription bei vielen Generalpausen in Varese-Partituren). ${ }^{27}$ Rihm is clearly aware of the alternative reading of such a title, that is, silence that must be 'defeated', and so he describes the silences as 'tormented, tortured (gepeinigt, gequält).' By extension, the substantive repeat of Chiffre [I] within Chiffre II is an element of the musical discourse which has also to 'be beaten'. Chiffre II becomes the frame which both encloses the earlier work and also comments upon it. The extended silence in Chiffre II therefore acts as the antithesis of the extensive quotation from Chiffre [I].

\section{'EIN KLANG ... FORMT SEINEN VORGÄNGER WILKLICH UM ${ }^{28}$}

\section{['A sound... really transforms its predecessor']}

Much has been written, not least by the composer himself, about his processes of 'spontaneous' composition whereby manipulation of musical ideas does not take place within a pre-planned framework through which the musical argument is articulated. Form and structure are rarely planned in advance: they emerge out of the progress of the musical discourse as it develops moment by moment. However in relation to this concept Rihm diverges from his teacher Stockhausen in the way in which he considers that a sound 'transforms its predecessor' through frequent recapitulatory or repoled moments which build relationships with what has come before, while at the same time providing the basis for what is to come.

Whether Rihm intends his listeners to perceive such structural elements is not clear but from his writings it is likely that he would prefer multiple interpretations such as suggested by Nattiez's comment that 'the listener will project configurations upon the work that do not always coincide with the poietic process. ${ }^{129}$ Although Rihm asserts that a 'sound '[...]' transforms its predecessor' this can only be true in the sense that we have a memory of the previous sound and, as listeners, our memory of what we heard must be shaped by what we presently hear. What Rihm seems to be suggesting here is that he is deliberately

\footnotetext{
26 The sketches show that Rihm began a work called Silence to be beaten in 1981 but at that stage only wrote five bars and stopped at the sixth. The orchestration is virtually the same as the final version of Chiffre II and the chords (extended Lenz), clusters, and lower string repeated notes demonstrate a link between Chiffre [I] and II. The sketches are held at the Paul Sacher Institute in Basle and are currently (2006) not catalogued.

27 Rihm, Ausgesprochen, Vol. II, p. 344. There is also another connection with Varese, by way of Artaud. In a radio introduction to the Chiffre cycle, (held at the Sacher Institute in Basle (in the informal sound archive associated with the Rihm collection)., Rihm refers to Varèse's unfinished work L'Astronome for which Artaud contributed text.

28 'Ein Klang, der einem anderen Klang zeitlich folgt, formt seinen Vorgänger wirklich um (A sound, which temporally follows another sound, really transforms its predecessor) from Mutation (Exkurse), in, Rihm, Ausgesprochen, Vol. I, p. 159.

$29 \quad$ Nattiez, Music and Discourse, p. 17.
} 
manipulating this memory. Table 1 and the discussion which follows present one possible interpretation of the process in operation in Chiffre [I].

Table 1 Chiffre [I] outline event analysis

\begin{tabular}{|c|c|c|}
\hline Section & $\begin{array}{l}\text { Bar } \\
\text { numbers }\end{array}$ & Discussion/Features \\
\hline \multicolumn{3}{|l|}{ Section 1} \\
\hline 1 (a) & $1-29$ & $\begin{array}{l}\text { Piano clusters and single repeated pitches, instrumental } \\
\text { chords; ends with single pitch } G \text { in octaves }\end{array}$ \\
\hline $1(\mathrm{~b})$ & $29-41$ & Motif 1 and 2(a,b) in piano, foregrounded \\
\hline $1(\mathrm{a})^{1}$ & $41-43$ & Very brief 'recapitulation' \\
\hline \multicolumn{3}{|l|}{ Section 2} \\
\hline $2(\mathrm{a} 1)$ & $43-59$ & $\begin{array}{l}\text { Piano dominates with triplet semiquavers; increased use of } \\
\text { repeated pitches; bass dyads and chords shared between piano } \\
\text { and other instruments; piano ends with Motif } 2 \text { (a) }\end{array}$ \\
\hline $2(\mathrm{a} 2)$ & $59-69$ & $\begin{array}{l}\text { Piano texture continues; lower register chords continue; piano } \\
\text { refers back to motif } 2(\mathrm{a}) \text {; instruments coalesce at } 66-7 \text { on } \\
\text { single pitch } \mathrm{B} b \text { against piano } E, A \text { dyad } \rightarrow \text { Lenz chord; } \\
\text { concludes with diminished } 7^{\text {th }} \text { chord }\end{array}$ \\
\hline 2 (b) & $69-74$ & Piano solo quasi-thematic statement using $g \#^{3}$ as focus pitch \\
\hline $1(\mathrm{~b})^{1}$ & $75-87$ & Quasi variation of Motif 1 \\
\hline \multicolumn{3}{|l|}{ Section 3} \\
\hline 3 (a) & $\begin{array}{l}88-95 \\
\text { meno mosso }\end{array}$ & $\begin{array}{l}\text { First new chordal idea based on perfect } 5^{\text {th }} \text {, probably derived } \\
\text { from } 2 \text { (a1), shared between lower strings and piano }\end{array}$ \\
\hline $2(\mathrm{a} 1)^{1}$ & $\begin{array}{l}96-103 \\
\text { Tempo } 1 \\
103-108 \\
\end{array}$ & $\begin{array}{l}\text { Piano figuration related to } 2 \text { (a1); anticlimax with triplet } \\
\text { rhythm in augmentation leading to silence at } \mathrm{b} .108 \text { pre- } \\
\text { ceded by rit. to slowest control tempo, crotchet }=40\end{array}$ \\
\hline 3 (b) & $\begin{array}{ll}109- \\
118\end{array}$ & $\begin{array}{l}\text { Second new chordal idea shared between all instruments and } \\
\text { piano }\end{array}$ \\
\hline \multicolumn{3}{|l|}{ Section 4} \\
\hline $\begin{array}{l}\text { (a) } \\
\text { quasi- } \\
\text { developmental }\end{array}$ & $\begin{array}{ll}119- \\
132\end{array}$ & $\begin{array}{l}\text { Piano has probable reference to repeated pitch } A \text { in } 1 \text { (a); } \\
\text { increased wind activity in semiquavers probably derived from } \\
2 \text { (a2), dominating piano part; instrumental components } \\
\text { parallel to piano at } 2 \text { (a1) }\end{array}$ \\
\hline $\begin{array}{l}1(\mathrm{~b})^{2} \\
\text { 'developmental' } \\
\text { recapitulation }\end{array}$ & $133-141$ & $\begin{array}{l}\text { Piano reasserts Motif } 2 \text { in the form first sketched by Rihm (i.e. } \\
\text { pitch content as in } 1 \text { (b) but not layout/texture); followed by } \\
\text { Motif } 1\end{array}$ \\
\hline
\end{tabular}




\begin{tabular}{|l|l|l|}
\hline 4 (b) & $142-$ & $\begin{array}{l}\text { Instrumental unison slowly building } g \#, c^{3}, g^{1} \text { chord } \rightarrow g^{1}, \\
d^{3} \text { dyad }\end{array}$ \\
\hline $4(\mathrm{a})^{1}$ & $149-$ & Brief varied recapitulation of 4 (a) (repoling) \\
\hline Section 5 & 152 & \\
\hline Coda & $153-176$ & $\begin{array}{l}\text { Emphasis on Lenz chords in piano 155-6 leads to repeated } c^{1} \\
\text { [making possible distant reference to 1 (a)]; two new ideas } \\
\text { appear, in opposition to each other }\end{array}$ \\
\hline
\end{tabular}

The division into sections in the above table is conditioned in part by the nature of the related musical material, as opposed to the 'aural event' approach adopted by Frisius. ${ }^{30} \mathrm{I}$ have suggested the endings or beginnings of sections largely based on reprise of previously heard materials or on the 'development' of musical ideas heard before. Perhaps the most structurally significant feature this demonstrates is the interleaving of previous sections within later ones [1(b) in 2, 2(a1) in 3, 1(b) in 4]. These 'repeats' are often associated, at least in part, with versions of the motifs. Such variation/repetition would fall within the scope of the generalised concept ofrepoling. ${ }^{31}$ This is certainly the case for Section 4 where, although I have used the term 'recapitulation' for the perceptual level at which we hear it, the actual musical detail of Section 4(a), for example, derives from previously heard material put into new contexts. ${ }^{32}$

It is possible that the silences which are an integral part of Chiffre II may well represent a repoling of the absence of sound which occurs at b. 108 in Chiffre [I] which is effectively the point of the Golden Section and hence, in this context, anticlimactic. This would relate directly to Rihm's conception of the process of repoling which is encapsulated in a general comment in the CD booklet for Chiffre $I V$ where he declares that '[...]' the components [of the earlier pieces] '[...]' might appear in an altered, re-poled constellation the day after $[\text {.... }]^{133}$ Nielinger-Vakil is certainly referring to this process in the discussion of repetition of thematic ideas in Rihm's Hölderlin Fragments which she describes as:

'[...]' just one example of the kind of associative logic of progression which governs each of his works (sometimes even series of works). However a sense of direction is deliberately

$30 \quad$ For comparison with Frisius's interpretation see the discussion following Ex. 3.

31 The Table highlights two examples of chordal repoling in this work where the $B b$ pitch in instruments is set against $E$, $A$ in piano [section 2(a2)] effectively a temporary bifurcation of the Lenz chord, and similarly the transposed version of the same chord which occurs in section 4(b).

32 Section 3, on the other hand, while having some connection with what has heard before is largely created from newly invented material.

33 The original text is 'Durchsicht früher Stücke' ruft die üblichen 'gemischten Gefühle' auf, deren Komponenten anderntags in veränderter, umgepolter Konstellation aufscheinen können: in the booklet for, Wolfgang Rihm: Trios 1969-1994, CD, Kairos 0012092KAI 1999/2000. (Wolfgang Hofer an interview with Wolfgang Rihm 10.3.2000, p. 12, English version p. 20). The translation in the CD booklet of 'anderntags' as 'the day after' may be misleading as it is more exactly 'on another day'. 
undermined. The composer's ideal after all is to 'create something from chaos '[...]' which against chaos and with chaos again ends up being chaos'. ${ }^{34}$

Nielinger-Vakil does not however agree with Peter Andraschke's assertion that no syntactic order rules the development of material in Rihm's music..$^{35}$ Although the building process in Rihm's music which he characterizes by the terms generative pole and repoling do not constitute a syntactic order in the strictest sense, it could be argued that his use of previously heard material in new contexts is syntactic order: recapitulation/development $\rightarrow$ repoling based on limited exposition. Rihm's music moves from state to state in a manner which is recognisably progressive (that is, not an unrelated series of events). His spontaneous composition method may indicate lack of absolute intent but it does not preclude the creation of order in the execution of the actual compositional activity. In short there is a difference between there being no pre-planned order and order being imposed on the musical material as it is being created. That Rihm's compositional process is a dynamic one can be shown by an examination of 'new' material at the opening of Chiffre II and the role of Chiffre [I] within the new work. ${ }^{36}$ An analysis of the sketch material for the first twelve bars of Chiffre II, although having the appearance of random jottings, shows that there are other connections with Chiffre [I] which go beyond the sectional repetition of parts of Chiffre [I] which is the most obvious feature of the later work. There are several ways of interpreting how this sketch material might be internally related (that is, within Chiffre II itself) and how connected to the earlier work. ${ }^{37}$ In Ex. 6 I suggest a number of ways in which the fragments which became the opening of Chiffre II might therefore be understood:

34 Carola Nielinger-Vakil, Quiet Revolutions: Hölderlin Fragments by Luigi Nono and Wolfgang Rihm, in, Music and Letters, Vol. 81 no. 2, (May 2000), p. 265: the quotation from Rihm comes from the interview Offene Stellen Abbiegen ins Andere first published in Reinhold Urmetzer, Wolfgang Rihm, (Stuttgart: Edition Patricia Schwarz 1988), pp. 95-6.

35 Peter Andraschke, Dichterischer Text und musikalischer Kontext in Zum Verhältnis von Zeitgenössischer Musik und Zeitgenössischer Dichtung, ed. Otto Kolleritsch, (Vienna: Universal Edition 1988) 84-101, quoted in Nielinger-Vakil Quiet Revolutions, pp. 267-8.

36 Given its location in the sketches, there is potentially also a relationship with Schattenstück but as it is not germane to this discussion I do not intend to pursue this here. Schattenstück was started in 1982, perhaps even as early as late 1981, but was not finished until 1984.

37 A similar connection may be observed in the instrumental layout at this point. The relationship between the piano and other instruments in this opening sequence is neutral - the material is shared, though in Rihm's conception of the interaction between the piano and instruments in the cycle as a whole it is difficult to say which is actually doubling which. However, an accelerando and crescendo over the next three bars (up to Fig. 1) take the new work into a repeat of Chiffre [I] sections 2 (a) and 2 (b), and here it is quite definitely the other instruments which double the piano, adding to the original instrumental texture which is still present. In other words, the doubling has been overlaid upon the earlier work. 
Ex 6: Possible derivations/connections of Chiffre II source material (from first sketch) of bb. 1-12

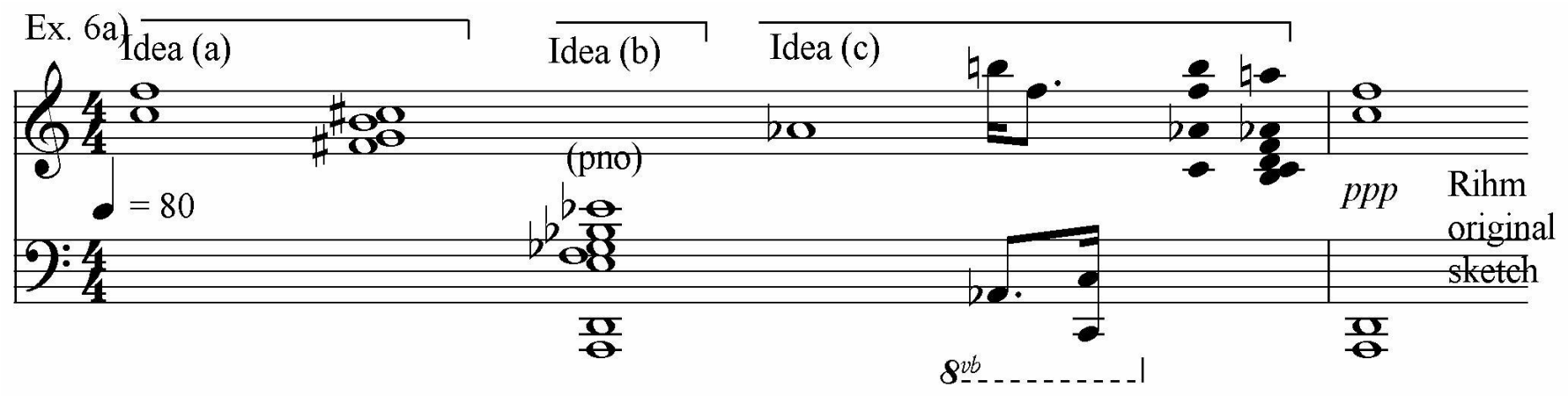

Ex. 6b)
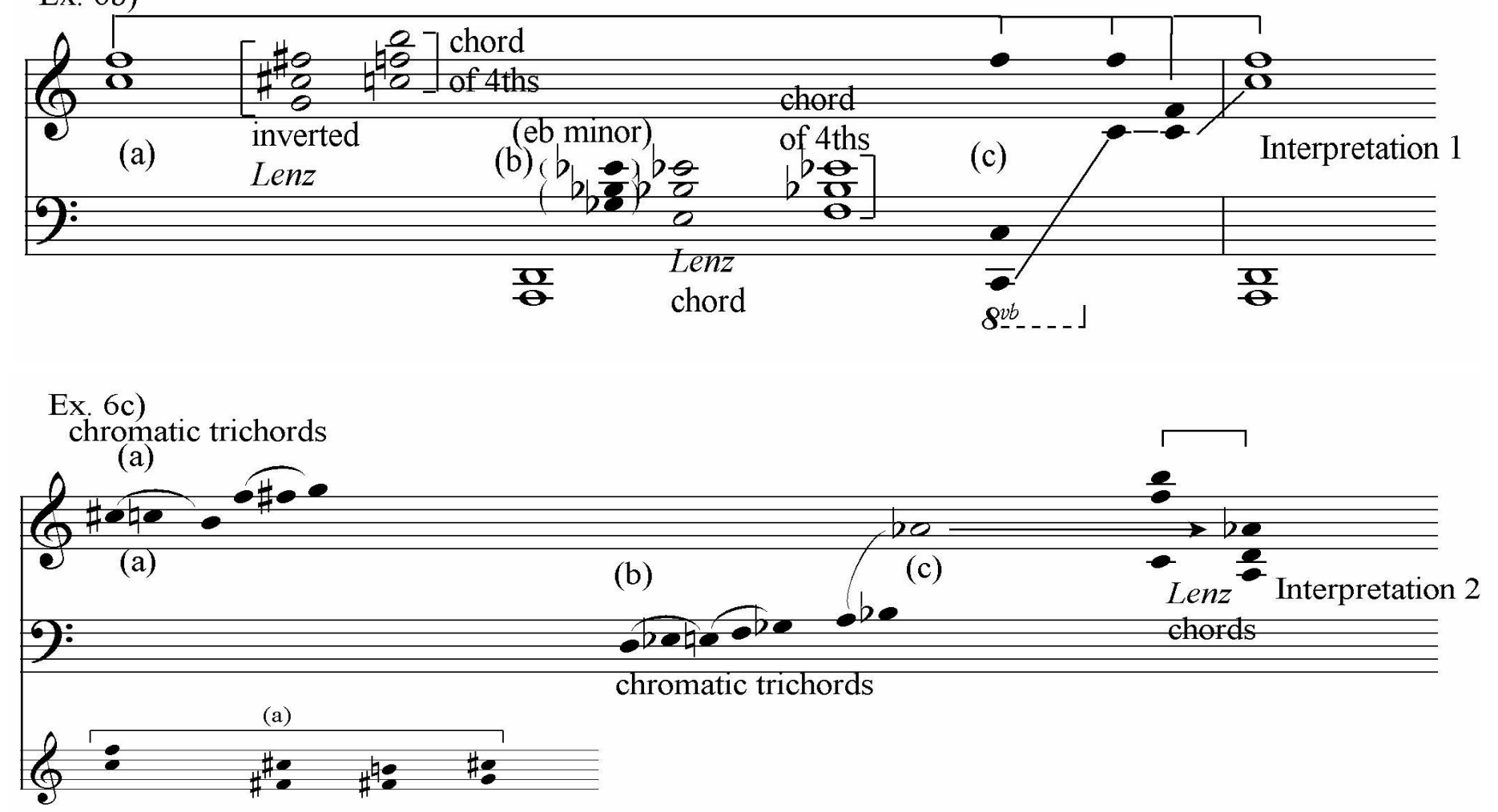

Ex. 6a is Rihm's original sketch material for the first 12 bars. In the first interpretation, Ex. 6 b, the pitches $F$ and $C$ act effectively as focal pitches with the opposing $4^{\text {th }}, D$ and $A$, in the bass. The second chord of the original can be interpreted as a version of the Lenz chord combined with an overlapping chord of fourths. ${ }^{38}$ The Lenz chord $c^{1}, f^{1}, b^{2}$ recurs towards the end of the sketch extract 'paired' with a transposed, inverted version of itself (end of Ex. 6c). However, an alternative reading of the opening pitches, in Ex. 6c, suggests that they can be grouped together as chromatic trichords (including some repetition of pitches) to give a 12-note group with the long $a b^{1}$ required to complete the chromatic trichord $b b, a, a b^{1}$. These trichords would therefore relate directly to the piano trichords in highest and lowest registers in Chiffre [I]. Since

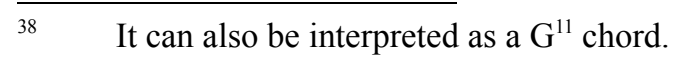


Rihm does not annotate his sketches it is not possible to say whether any or all of these connections were intended, or just 'spontaneous', which, it must be said, seems highly unlikely. ${ }^{39}$

Table 2 presents an overview of the whole of Chiffre II to demonstrate the repoling of Chiffre [I] within it. It is possible to listen to the work without knowing the earlier one, but Chiffre II certainly cannot be interpreted analytically except in relation to Chiffre [I]. As the table below shows, the relationship is not simply just about the repetition of significant sections of the previous work: there is a sense in which the earlier work is struggling to 'regain' its own sectional identity. This is particularly relevant to the position of the piano in Chiffre II. The opposition between the piano and the other instruments builds on the relationship established in the earlier work, and, while it might evoke associations with concerto Rihm's use of the registral extremes of the piano is clearly intended to militate against such associations. Notwithstanding this, the use of strongly characterized motivic features which are placed in opposition to, or shared between, the piano and the instruments, as well as the deliberate recapitulation of material, both tend to reinforce the traditional stereotypes. It is difficult to view the, albeit brief, unison or octave passages as other than orchestral tutti. The paradox which this creates in the work - the opposition of a new means of expression against older stereotypes - contributes significantly to the work's dramatic tension.

Table 2 Chiffre II Silence to be Beaten - key components

\begin{tabular}{|c|c|c|c|c|}
\hline Section & $\begin{array}{l}\text { Rehearsal } \\
\text { Letters }\end{array}$ & $\begin{array}{l}\text { Length } \\
\text { in bars }\end{array}$ & $\begin{array}{l}\text { Relationship to new material and relationship with Chiffre } \\
{[I]}\end{array}$ & $\begin{array}{l}\text { Formal } \\
\text { Structure }\end{array}$ \\
\hline & & & $\begin{array}{l}\text { Key: NEW - new material often taken from sketches; REF- } \\
\text { repeated (repoled) material from Chiffre [I]; RPT - } \\
\text { repetition or repoling of material from Chiffre II only }\end{array}$ & \\
\hline $\begin{array}{l}\text { Section } \\
1\end{array}$ & $\begin{array}{l}\text { Opening } \\
\text { to L }\end{array}$ & 69 & & \\
\hline \multirow{6}{*}{$\begin{array}{l}\text { Opening } \\
\text { to E (44 } \\
\text { bars) }\end{array}$} & $\begin{array}{l}\text { Opening } \\
-\mathrm{B}\end{array}$ & 15 & NEW chords at bb. 1, 2, 9-12 (as Ex. 6) & $1 \mathrm{a}$ \\
\hline & B - E & $\begin{array}{l}24 \\
(+5)\end{array}$ & $\begin{array}{l}\text { REF Chiffre [I] quoted sections 2(a) and 2(b) exactly; } \\
\text { piano in final } 5 \text { bars quotes repeated } a^{4} \text { from } \\
\text { Chiffre [I] Section 1(a) }\end{array}$ & $1 \mathrm{~b}$ \\
\hline & $\mathrm{E}-[\mathrm{I}]$ & 25 & & \\
\hline & $(E-F)$ & (9) & $\begin{array}{l}\text { NEW upper wind + high trpt: melodic/harmonic content } \\
\text { REF Piano: Ex Chiffre [I] Section 1(a) }\end{array}$ & $1 c / 1 b$ \\
\hline & $(F-G)$ & (5) & $\begin{array}{l}\text { NEW repetitive idea - [all new detail sketched] } \\
\text { REF Use of material from Chiffre [I] continues (pno) }\end{array}$ & $1 d / 1 b$ \\
\hline & $(\mathrm{G}-\mathrm{H})$ & (6) & $\begin{array}{l}\text { REF Strings: first appearance of expanded version of } \\
\text { Chiffre [I] chord (e) } \\
\text { REF piano: Chiffre [I] section 1(a) material continues } \\
\text { in new context }\end{array}$ & (cont.) \\
\hline
\end{tabular}

39 The opening dyad $c^{3}, \beta^{3}$ of Chiffre II is clearly connected to the opening bar of Chiffre [I]. Since it is a dominant feature of the first 12 bars of Chiffre II the links with the earlier work are enhanced by the disposition of pitch content within the instrumental groupings. 


\begin{tabular}{|c|c|c|c|c|}
\hline Section & $\begin{array}{l}\text { Rehearsal } \\
\text { Letters }\end{array}$ & $\begin{array}{l}\text { Length } \\
\text { in bars }\end{array}$ & $\begin{array}{l}\text { Relationship to new material and relationship with Chiffre } \\
\text { [I] }\end{array}$ & $\begin{array}{l}\text { Formal } \\
\text { Structure }\end{array}$ \\
\hline & $(\mathrm{H})-(\mathrm{I})$ & (5) & $\begin{array}{l}\text { RPT varied repeat of new melodic motif from E (now } \\
\text { fl. and str., remaining } 3 \text { bars are repeated pitches } \\
\text { on most instruments } \\
\text { REF 'coalescence' with Chiffre [I] }\end{array}$ & $1 c^{1}$ \\
\hline & $\mathrm{I}-\mathrm{L}$ & & & \\
\hline & & 56 & $\begin{array}{l}\text { Long held celli harmonic } F \text {; first occurrence of silence ( } 2 \\
\text { x G.P.); extended roll on } 2 \text { x große Trommel }\end{array}$ & $\begin{array}{l}\text { 1d or Stasis } \\
\text { Point } 1\end{array}$ \\
\hline \multirow{4}{*}{$\begin{array}{l}\text { Section } \\
2\end{array}$} & $\mathrm{~L}-\mathrm{N}$ & 29 & & \\
\hline & $(\mathrm{L})-(\mathrm{M})$ & (9) & $\begin{array}{l}\text { NEW i) (Motif A) } \\
\text { REF piano reference to Chiffre [I] section 1(a) (2 bars } \\
\text { Only) } \\
\text { NEW ii) shared piano and string semiquaver idea }\end{array}$ & $\begin{array}{l}2 \mathrm{a} \\
2 \mathrm{~b} / \\
\left(1 \mathrm{~b}^{1}\right) \\
\end{array}$ \\
\hline & $(\mathrm{M})-(\mathrm{N})$ & (15) & $\begin{array}{l}\text { NEW short section with irregular chords, short } \\
\text { thematic fragments, and repeated pitches; } \\
\text { REF piano - a brief reference to Chiffre [I] 1(a)- } \\
\text { isolated short interjections }\end{array}$ & $\begin{array}{l}2 \mathrm{c} / \\
\left(1 \mathrm{~b}^{2}\right)\end{array}$ \\
\hline & $\mathrm{N}-\mathrm{T}$ & 53 & Section with changes of time signatures $(\mathrm{N}-\mathrm{Q})$ & \\
\hline \multirow[t]{4}{*}{$\begin{array}{l}\text { Section } \\
3\end{array}$} & $(\mathrm{~N})-(\mathrm{P})$ & (17) & $\begin{array}{l}\text { NEW upper brass and oboe thematic idea in fifths, over } \\
\text { string cluster (Motif A varied); extended in wind } \\
\text { and brass with accel. to Fig. P (Motif A extended); } \\
\text { repeated with more instruments and third line in } \\
\text { parallel, at an octave + tritone (Motif A third } \\
\text { variation) }\end{array}$ & $3 a+v$ \\
\hline & $(P)-(Q)$ & (7) & $\begin{array}{l}\text { NEW i) idea shared among piano, wind, brass and } \\
\text { strings } \\
\text { RPT ii) piano figuration using repeated chords from } \\
\text { REF Fig. L and Fig. } \mathrm{M}^{+8} \text {, then repeat of Chiffre [I] } \\
\text { 1(a) cluster idea repoled }\end{array}$ & $\begin{array}{l}3 \mathrm{~b} \\
\left(2 \mathrm{a}^{1 / c^{1}}\right. \\
\left./ 1 \mathrm{~b}^{3}\right)\end{array}$ \\
\hline & $(\mathrm{Q})-(\mathrm{R})$ & (12) & $\begin{array}{l}\text { RPT i) brass Motif A in diminution probably intended to } \\
\text { contain elements of parody } \\
\text { (REF)ii) piano repeated } c^{4} \text { recalling Chiffre [I] } \\
\text { (later with woodblocks and viola) }\end{array}$ & $3 \mathrm{c} / 1 \mathrm{~b}^{4}$ \\
\hline & $(\mathrm{R})-(\mathrm{T})$ & (17) & $\begin{array}{l}\text { NEW i) (R) - (S) } 10 \text { bars new material continues ending } \\
\text { with } 1 \text { bar G.P. } \\
\text { REF Return of } a^{4} \text { as at Fig I in piano } \\
\text { NEW ii) (S) - (T) } 4 \text { bars continuation ending with silent } \\
\text { pause followed by } 2 \text { bars G.P. } \\
\text { REF Reference to repoled Chiffre [I] figuration leading } \\
\text { to G.P. }\end{array}$ & $\begin{array}{l}\text { Stasis Point } \\
2\end{array}$ \\
\hline
\end{tabular}




\begin{tabular}{|c|c|c|c|c|}
\hline Section & $\begin{array}{l}\text { Rehearsal } \\
\text { Letters }\end{array}$ & $\begin{array}{l}\text { Length } \\
\text { in bars }\end{array}$ & $\begin{array}{l}\text { Relationship to new material and relationship with Chiffre } \\
{[I]}\end{array}$ & $\begin{array}{l}\text { Formal } \\
\text { Structure }\end{array}$ \\
\hline \multirow{5}{*}{$\begin{array}{l}\text { Section } \\
4\end{array}$} & $\mathrm{~T}-\mathrm{X}$ & 26 & & \\
\hline & $(\mathrm{T})-(\mathrm{U})$ & $(11)$ & $\begin{array}{l}\text { REF string chord probably related to Chiffre [I] chord } \\
\text { (e) (via Fig. } \mathrm{G}^{+4 ?} \text { and Fig. } \mathrm{M}^{+3} \text { ) } \\
\text { REF piano reference to Chiffre [I] 1(a) } \\
\text { NEW remaining material probably new } \\
2 \text { silent bars with piano ring-on only }\end{array}$ & $\begin{array}{l}\mathrm{a} \\
\left(1 \mathrm{~b}^{5}\right) \\
\\
\text { Stasis } \\
\text { Point } 3\end{array}$ \\
\hline & $(\mathrm{U})-(\mathrm{V})$ & (3) & $\begin{array}{l}\text { NEW brass and wind brief link with possible reference } \\
\text { to Fig. } \mathrm{O}^{+3} ; c \#^{2} / g \#^{2} \text { dyad links to: }\end{array}$ & $4 b / 3 a^{1}$ \\
\hline & $(\mathrm{V})-(\mathrm{W})$ & (6) & $\begin{array}{l}\text { REF } 5 \text { bars quoted from Chiffre [I] section } 2(\mathrm{a} 1)^{1}[\mathrm{~b} \text {. } \\
\text { 96] with added string repeated chord possibly } \\
\text { derived from accompanying parts in Chiffre [I] at } \\
2(\mathrm{a} 1)^{1} \text { and perhaps also Chiffre [I] chord (e); final } \\
\text { bar extended in piano to terminus chord as at Fig. } \\
\mathrm{M}^{+5}\end{array}$ & $1 b^{v} / 2 c^{1}$ \\
\hline & $(\mathrm{W})-(\mathrm{X})$ & (6) & $\begin{array}{l}\text { (RPT) piano refers back to Fig. } \mathrm{M}^{+5} \text {; otherwise varied } \\
\text { repeat of fig. U material }\end{array}$ & $4 b^{1} / 2 c^{1}$ \\
\hline$C O D A$ & $(\mathrm{X})-\mathrm{end}$ & 18 & NEW & $C O D A$ \\
\hline
\end{tabular}

Rihm treats the piano as the instrument which etches itself onto the musical surface of the other instruments, although there are also some key points of coalescence. In the first section these are specifically the string chord between Figs $\mathrm{G}$ and $\mathrm{H}$ which is a repoled form of a chord (e) from the opening chordal sequence of. Chiffre [I]

Ex 7: chord (e in Ex. 1) repoled in Chiffre II at Fig G+4

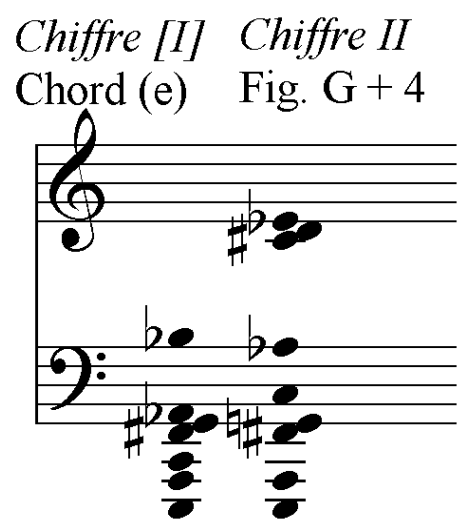

This leads to Figs $\mathrm{H}$ - I where the instruments are drawn into the piano texture which acts as the catalyst for the reduction of density towards silence at the end of the first section. Thus if there is a symbolic gesture in the 'defeat' of the piano in Chiffre VI, then Chiffre [I] is its diametric opposite: as the work 
progresses the piano constantly reasserts the Chiffre [I] material, writing itself onto the instrumental texture. $^{40}$

\section{KLANGSCHRIFT (Soundscript)}

Many twentieth-century composers develop a meta-language in order to analogize the musical processes they undertake through composition. Rihm's concern with linguistic expression, which is an extension of the extraordinarily detailed articulation instructions in his scores, is evident in his programme notes, and especially those from 1980. These eschew the typical descriptive format in favour of process statements in his meta-language. In short, the programme notes become verbal analogies of the works they purport to describe: isolated words; phrases; points; juxtaposition of random thoughts; key words; words with multiple meanings; unfinished sentences; questions (without answers). The way the music is, Rihm translates into words through, as Nielinger-Vakil puts it in relation to the music, 'the structural juxtaposition of self-contained musical aphorisms'. ${ }^{41}$

As an expression of the compositional processes to be found in his works the words are deliberately ambiguous. Writing about Zeichen, Rihm says: 'The term Sign is a central concept of my musical thinking. To the Sign belongs: the Setting. The act of creating signs is an act of freedom. The sound writes itself as script, soundscript. ${ }^{42}$

Rihm's use of Sign and Setting in relation to the Klangraum not only evokes a visual metaphor but suggests semiotic meanings which are almost certainly from the theatre and probably from Artaud. ${ }^{43}$ It is always important to consider what Rihm's programme notes say about the particular work in relation to the processes embodied within it.

\footnotetext{
40 The use of a previous work as a generative pole for another in the same cycle is an idea employed subsequently by Rihm in works such as the Vers une Symphonie Flueve (1992-2000) cycle.

41 So it is possible to map directly the features of Rihm's musical style against the language of his programme notes:

single pitches - isolated words

short musical phrases - short verbal phrases

pitch flourishes - 'random' juxtapositions of words

dominance of $4^{\text {th }} / 5^{\text {th }}$ intervals - use of key words

chords of varying density - words with multiple meanings

repetitive rhythms - unfinished sentences

silence - questions (without answers)/rhetorical questions

$42 \quad$ 'Der Begriff "Zeichen" ist ein Zentralbegriff meines musikalichen Denkens. Zum Zeichen gehört: die Setzung. Der Akt der Zeichensetzung ist ein Akt der Freiheit. Der Klang schreibt sich als Schrift, Klangschrif't, in, Rihm Ausgesprochen, Vol. II, p. 343.

43 Rihm uses vocabulary derived from Artaud to signify the musical ideas, and, particularly in the works of the $80 \mathrm{~s}$, to give the very titles of new works, as for example Zeichen (1983-85), Klang[beschreibung] (1982-7), Chiffre (198285/88), and later, In-schrift (1995).
} 
The above discussion has provided a vocabulary with which to interrogate key aspects of Rihm's compositional process in the Chiffre cycle whilst working within a controlled framework for an analysis. The characteristics of Chiffre [I] and Chiffre II have been quite readily definable and these can be shown to underpin compositional processes working within later works in the cycle. Notwithstanding this, a number of questions will need to be addressed. For example, none of the subsequent Chiffre works makes such detailed or extensive reference to a previous work in the series: considering the example of Chiffre [I] and II, why not? This leads us to ask why the remaining works in the cycle are Chiffre at all? Are the defining elements of the Chiffre series strong enough to give unity to the cycle as a whole? In the following section I attempt to give an answer to these questions through analysis of a key later work in the cycle: Chiffre VI. 